\title{
Floating Rowcovers Improve Germination and Reduce Carrot Weevil Infestations in Carrot
}

\author{
Djamila Rekika and Katrine A. Stewart \\ Department of Plant Science, Macdonald Campus, McGill University, \\ Ste-Anne-de-Bellevue, Quebec, H9X 3 V Canada
}

Guy Boivin and Sylvie Jenni ${ }^{1}$

Agriculture and Agri-Food Canada, Horticultural Research and Development Centre, 430 Gouin Boulevard, St-Jean-sur-Richelieu, Quebec, J3B 3E6 Canada

Additional index words. Daucus carota, Listronotus oregonensis, agrotextile, pest control, biological control

\begin{abstract}
A lightweight agrotextile floating rowcover $\left(10 \mathrm{~g} \cdot \mathrm{m}^{-2}\right)$ designed for insect control was evaluated for its potential to reduce carrot weevil [Listronotus oregonensis (Le conte)] damage and to improve germination and carrot (Daucus carota L.) yield. The floating rowcover had no effect on total emergence and spread on emergence time but decreased emergence time by 0.5 day. Although floating rowcovers generally increased fresh weight of carrot leaves and roots during early development, no effect was detected late in the season and at harvest time. Carrot weevil damage of uncovered plants was 0.4 tunnels per root in 2006 and 2.0 tunnels per root in 2005. In both years, covering carrots with a floating rowcover for a period of 35 days after sowing reduced carrot weevil damage by $65 \%$ to $75 \%$. In most years with low or medium carrot weevil infestation, the use of a rowcover could eliminate the use of insecticide to control this pest.
\end{abstract}

The carrot weevil, Listronotus oregonensis (Le conte), is the most significant pest of carrot (Daucus carota L.) crops in Quebec, where more than $40 \%$ of the crop may be damaged if the weevil is left uncontrolled (Zhao et al., 1991). Carrots become attractive to the weevil at approximately the four-trueleaf stage. The female lay eggs in slits on the petioles of the leaves. Newly hatched larvae fall to the ground and begin feeding externally on the root. Damage is usually limited to the crown and top one-third of the root, causing the carrot to lose its fresh market value. In Quebec, the maximum damage tolerated by growers is $\approx 2 \%$ (Boivin, 1999).

Management of this pest is done mostly through chemical insecticides; however, concern over pesticide use has increased considerably among growers and the general public. The potential adverse effects of pesticides on the environment coupled with the development of insect resistance suggest that there is a great need to evaluate alternative control strategies to replace or reduce pesticide use.

\footnotetext{
Received for publication 16 Jan. 2008. Accepted for publication 24 Apr. 2008.

This study was supported by funding from Quebec's Ministère de l'Agriculture, des Pêcheries et de l'Alimentation (MAPAQ) under the horticultural innovation support program.

Use of trade names does not imply endorsement of the products named or criticism of similar ones not named.

${ }^{1}$ To whom reprint requests should be addressed; e-mail jennis@agr.gc.ca
}

Agrotextile floating rowcovers are already being used successfully to manage insect pests and the viruses they transmit to vegetable crops such as radish (Rekika et al., 2008; Wells and Loy, 1985), cauliflower (Millar and Isman, 1988), muskmelon (Perring et al., 1989), zucchini (Costa et al., 1994), melon (Farias-Larios et al., 1999; Orozco et al., 1994), and winter squash (El-Zammar et al., 2001). In carrot, rowcovers have prevented carrot fly attack in a strategy to reduce pesticide use (Davies and Collier, 2000) or for organic production (Peacock, 1991).

In addition to pest control, floating rowcovers modify the microclimate surrounding the plants and potentially provide a less stressful growing environment (Lamont, 2005). However, under some conditions, they can create supraoptimal temperatures deleterious to the crop and must be removed (Benoit and Ceustermans, 1990). To reduce this problem, lighter agrotextile materials were developed to alleviate heat stress allowing them to remain on the crop for longer periods for insect protection. Floating rowcovers readily allow percolation of water and spread the impact of the water droplets over a larger surface area, reducing soil compaction (Lamont, 1996; Wells and Loy, 1993). This feature is particularly important for seeded crops such as carrot in which soil crusting caused by rainfall or irrigation and occurring shortly after sowing is a major cause of poor emergence (Finch-Savage, 1986; Hartz, 1994).

The objectives of this study were to evaluate the influence of an agrotextile floating rowcover on germination and growth of carrot and to determine its effectiveness in preventing carrot weevil damage in relation to varying covering periods.

\section{Material and Methods}

The experiments were conducted on muck soil at the Agriculture and Agri-Food Canada Experimental Farm at Ste-Clotilde (lat. $45^{\circ} 10^{\prime} \mathrm{N}$, long. $73^{\circ} 41^{\prime} \mathrm{W}$ ) during 2005 and 2006. Before sowing, the soil was fertilized ( $\mathrm{N}$ at $218 \mathrm{~kg} \cdot \mathrm{ha}^{-1}, \mathrm{P}$ at $108 \mathrm{~kg} \cdot \mathrm{ha}^{-1}$, and $\mathrm{K}$ at $137 \mathrm{~kg} \cdot \mathrm{ha}^{-1}$ ) on the basis of soil tests, and neither insecticide nor fungicide was applied. Weeds were controlled by the application of an herbicide at sowing (Lorox L at a rate of 2.25 L $\cdot \mathrm{ha}^{-1}$, Linuron; DuPont, Mississauga, Ontario, Canada) and later by handweeding.

Germination experiment. To determine the effect of an agrotextile floating rowcover on carrot emergence, seeds were handseeded on $27 \mathrm{Apr} .2006$ in $1.8 \times 1-\mathrm{m}$ beds containing two rows of 50 seeds. In each block, two outer rows of carrot served as guards. The plots with an Agryl P10 floating rowcover (Plastitech Culture, St-Rémi, Quebec, Canada), a lightweight $\left(10 \mathrm{~g} \cdot \mathrm{m}^{-2}\right)$, nonwoven polypropylene designed for insect control, were compared with control (no floating rowcover) plots. The floating rowcover was applied immediately after sowing on plots arranged in a randomized complete block design with four replicates. Emerged seedlings were counted daily when they reached the cotyledon stage. After a period of $5 \mathrm{~d}$ with no further emergence, seedling counts were ended. Percentage emergence, mean emergence time in days, and spread of emergence in days were calculated as described by Orchard (1977).

Growth and insect control. Carrot seeds (cv. Cellobunch) were sown on 6 May 2005 and $20 \mathrm{Apr} .2006$ in beds $0.84 \mathrm{~m}$ wide using a pneumatic precision seeder (Gaspardo model V-20; Morsano, Italy) at a rate of 100 seeds per linear meter. Plots were $5 \mathrm{~m}$ long with three rows (one experimental and two guard rows) spaced $30 \mathrm{~cm}$ apart. In each block, three outer rows of carrot served as guards. In 2005, plots were sprinkler-irrigated with $12.5 \mathrm{~mm}$ of water on 2, 3, and 30 June and no irrigation was applied in 2006. The eight treatments were seven covering periods with the agrotextile floating rowcover (Agryl P10) and no floating rowcover (control). The floating rowcovers were installed 3 to $6 \mathrm{~d}$ after sowing to allow for the application of the preemergent herbicide and secured with soil along all edges of the bed, leaving sufficient slack to allow plant growth. The first uncovering occurred when $50 \%$ of seedlings had emerged in control plots, i.e., 26 May 2005 and 5 May 2006. Floating rowcovers were then removed weekly for the next 7 weeks ending on 7 July 2005 and on 16 June 2006. The treatments were arranged in a randomized complete block design with four replicates.

Air temperature was measured at $5 \mathrm{~cm}$ above soil surface using copper-constantan thermocouple sensor probes connected to a 
data acquisition system (Testo, model 177T40, ITM Instruments, Quebec, Canada). The thermocouple sensor probes were housed in a radiation shield and placed in uncovered (control) and covered plots. Temperatures were recorded at 10-min intervals and averaged every hour from sowing until harvest.

To determine the effect of the floating rowcover on the growth of carrot, fresh weights of leaves and roots were recorded from a sample of 30 plants at each cover removal time. Final harvest was performed on a $1-\mathrm{m}$ section of the inner row on 21 July 2005 and 10 July 2006, when the plants in the covered plot (41 and $36 \mathrm{~d}$ of covering) reached a diameter ranging between 19 and $26 \mathrm{~mm}$, a standard used by growers.

Carrot weevil damage was assessed at harvest by evaluating root injury on randomly selected roots on a $1-\mathrm{m}$ section of the inner row. Roots were visually inspected and dissected to determine the number of feeding tunnels. All data were subjected to an analysis of variance using the GLM procedure of SAS (SAS Institute, 1989). When treatment effects were significant $(P<0.05)$, differences among means were determined using a least significant differences test. The number of feeding tunnels was transformed using $\log (x+1)$ to stabilize variance. Logistic dose-response curves were used to estimate the number of days with covers required to achieve a $50 \%$ reduction in damage caused by carrot weevils using the computer Table Curve 2D (version 5.01; Systat Software, San Jose, CA).

\section{Results and Discussion}

Mean air temperatures in uncovered plots, from seeding until the last floating rowcover removal, were 18.0 and $14.5^{\circ} \mathrm{C}$ in 2005 and 2006, respectively. Mean air temperatures were generally higher under the floating rowcover with an average increase in temperature of 1.4 and $1.2^{\circ} \mathrm{C}$ in 2005 and 2006, respectively.

Under the rowcover, 51\% emergence was achieved $12 \mathrm{~d}$ after seeding compared with $30 \%$ for the uncovered plots (Fig. 1). Thirteen days after seeding, the two treatments reached $\approx 80 \%$ germination. There was no rowcover effect on total percentage emergence (Table 1). The rowcover reduced mean emergence time from 13.1 to $12.6 \mathrm{~d}$ but did not affect spread of emergence. The reduction in emergence time was less than that reported by both Finch-Savage (1986), 7 d, and Jenni (1989), 2 d, who covered carrots with polyethylene film and minicarrots with polypropylene, respectively. The difference may reflect the different weight of the floating rowcovers. The lightweight material used here had no significant effect on total emergence, but slightly decreased mean emergence time, likely by increasing air and soil temperature and reducing soil impedance (Finch-Savage et al., 1998, 2001; Hartz, 1994).

In both years, floating rowcovers generally increased the fresh weight of carrot leaves and roots, although this was not

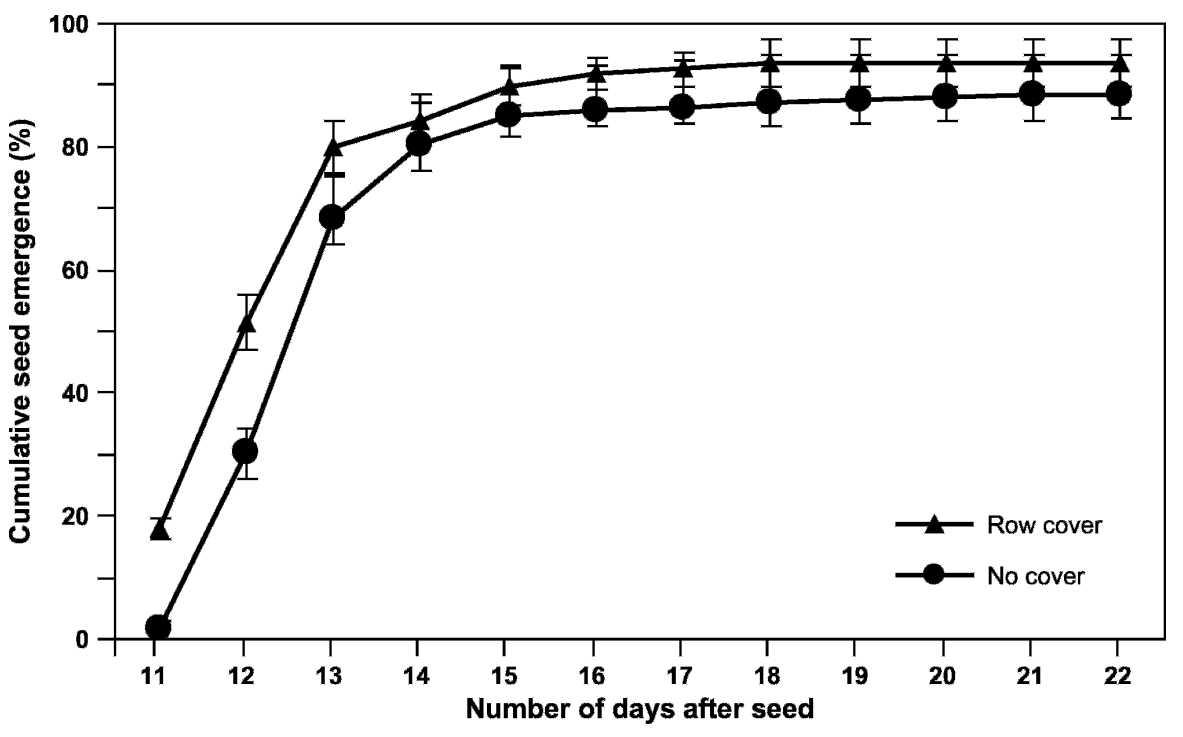

Fig. 1. Effect of a lightweight floating rowcover $\left(10 \mathrm{~g} \cdot \mathrm{m}^{-2}\right)$ on cumulative percent emergence of 'Cellobunch' carrot. Bars represent SD of four replicates.

Table 1. Effect of a lightweight floating rowcover $\left(10 \mathrm{~g} \cdot \mathrm{m}^{-2}\right)$ on percent emergence, mean emergence time, and spread of emergence time of 'Cellobunch' carrot seedlings.

\begin{tabular}{lccc}
\hline Treatment & Emergence $(\%)$ & $\begin{array}{c}\text { Mean emergence } \\
\text { time (days) }\end{array}$ & $\begin{array}{c}\text { Spread of } \\
\text { emergence (days) }\end{array}$ \\
\hline No rowcover & $88.5(70.9)^{\mathrm{z}}$ & 13.1 & 1.9 \\
Row cover & $93.5(83.3)$ & 12.6 & 1.3 \\
LSD $^{\mathrm{y}}$ & $\mathrm{NS}$ & 0.4 & $\mathrm{NS}$ \\
\hline
\end{tabular}

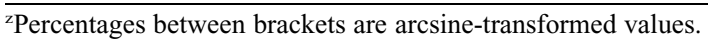

y Protected least significant difference at the $5 \%$ level of significance.

Nonsignificant.

always significant during the 2005 growing season. The late irrigation during the dry growing season in 2005 may have contributed to this lack of response. After 62 and $57 \mathrm{~d}$ of covering, leaf and root weights of covered plants were similar to those of the control (Fig. 2) and this trend was maintained through to the final harvest.

At harvest, the carrot plants grown under different covering periods did not differ in fresh root and leaf $(P>0.05)$ from those with no floating rowcover. For all treatments, on average, leaf length was $53 \mathrm{~cm}$ and $59 \mathrm{~cm}$; leaf weight, $22 \mathrm{~g}$ and $21 \mathrm{~g}$; root diameter, $22 \mathrm{~mm}$ and $22 \mathrm{~mm}$; root length, $15 \mathrm{~cm}$ and $17 \mathrm{~cm}$; and root weight, $33 \mathrm{~g}$ and $34 \mathrm{~g}$ in 2005 and 2006, respectively. These results contrast with those of Jenni (1989), in minicarrots, and Benoit et al. (1983), in standard carrots, who found that covered plants resulted in larger roots and better developed foliage compared with uncovered plants. The lighter weight and the lower thermal properties of the floating rowcover than covers used in the previous studies might account for the results obtained in our experiments.

When crops were harvested at optimal maturity, carrot weevil damage decreased with a period of protection after a logistic dose-response curve (Fig. 3). Removing the rowcover after 18 or $20 \mathrm{~d}$ did not provide enough protection against carrot weevil damage $(P>0.05)$. In both years, damage started to decline when the covering period exceeded $20 \mathrm{~d}$ (Fig. 3). The damage to carrot continued to decrease with a longer covering period (between 25 and $40 \mathrm{~d}$ ), reaching a plateau after $40 \mathrm{~d}$ of covering (Fig. 3). This study confirms previous work of Davies and Collier (2000), which showed that an agrotextile floating rowcover can be used to prevent carrot fly, Psila rosae (Diptera: Psilidae) infestations.

Oviposition by carrot weevil females and subsequent damage intensity is related to the accumulation of degree-days with a base temperature of $7{ }^{\circ} \mathrm{C}\left(\mathrm{DD}_{7}{ }^{\circ} \mathrm{C}\right)$ and to the phenological stage of carrot (Boivin, 1999). According to the prediction model currently used in the monitoring program for carrot weevil, oviposition starts at $147 \mathrm{DD}_{7}{ }^{\circ} \mathrm{C}$ and $90 \%$ of eggs are deposited by $456 \mathrm{DD}_{7}{ }^{\circ} \mathrm{C}$ (Boivin, 1988). Furthermore, egg laying does not start until carrots reach the four-true-leaf stage. In 2005, carrots that were covered for less than $30 \mathrm{~d}$ were available to oviposition by carrot weevil females and showed rather high carrot weevil damage (Fig. 3). Plants that reached the susceptible developmental stage while the floating rowcover was in place (greater than $40 \mathrm{~d}$ ) escaped most carrot weevil ovipositioning and subsequent damage. Based on calculations using the degreeday accumulation $\left(456 \mathrm{DD}_{7}{ }^{\circ} \mathrm{C}\right)$ model, $90 \%$ of the eggs were laid $\approx 20$ June 2005 , i.e., $17 \mathrm{~d}$ before the removal of the last floating rowcover. The low damage recorded after $34 \mathrm{~d}$ of covering could coincide with the end of carrot weevil oviposition, even when the plants were left uncovered after the critical four-leaf stage. 

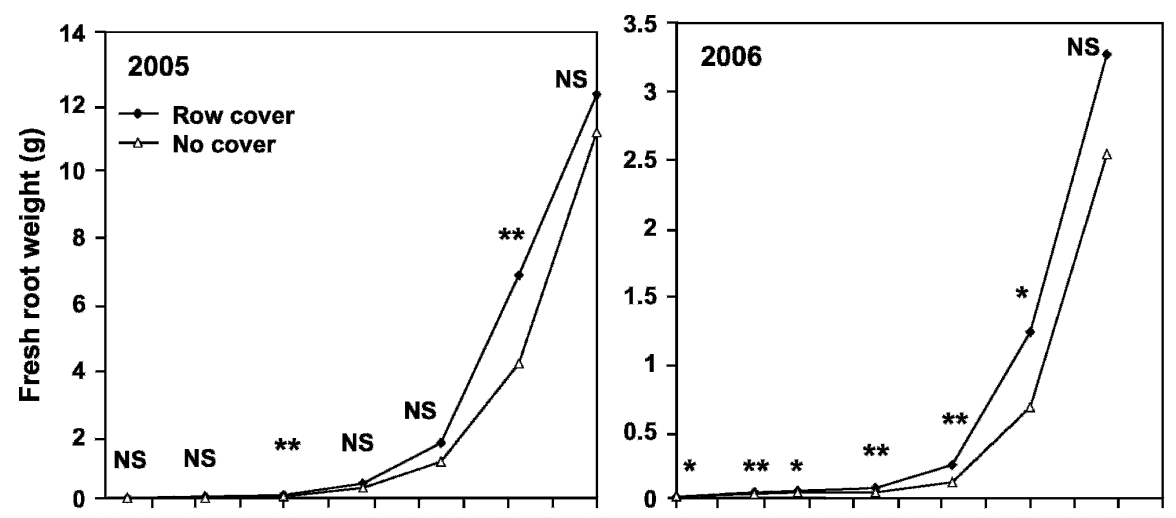

$\begin{array}{llllllllllll}18 & 22 & 26 & 30 & 34 & 38 & 42 & 46 & 50 & 54 & 58 & 62\end{array}$

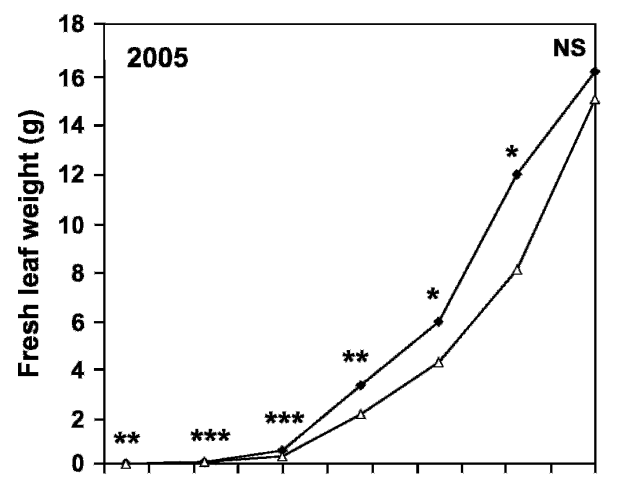

$\begin{array}{llllllllllll}18 & 22 & 26 & 30 & 34 & 38 & 42 & 46 & 50 & 54 & 58 & 62\end{array}$

Days of covering

Fig. 2. Effect of lightweight agrotextile floating rowcover $\left(10 \mathrm{~g} \cdot \mathrm{m}^{-2}\right)$ on leaves and root weight of $30 \mathrm{carrot}$ plants. Each point represents the means of four replicates. The rowcover was removed at the time of sampling. ${ }^{\text {Ns,****,**** Nonsignificant or significant at } P \leq 0.05,0.01,0.001 \text {, respectively, tested by analysis }}$ of variance.

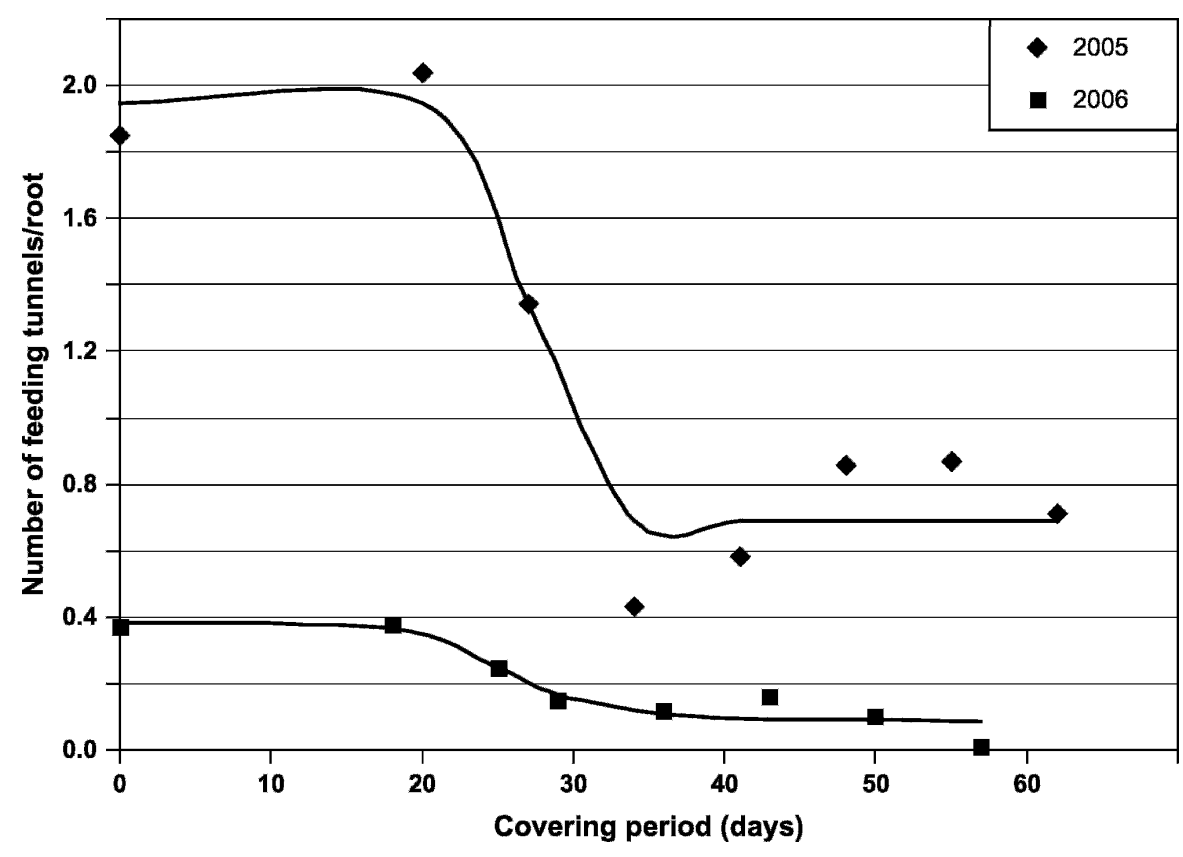

Fig. 3. Effect of covering period with an agrotextile floating rowcover on carrot weevil damage in carrots grown in (A) 2005 and (B) 2006 in southwestern Quebec. Carrot weevil damage was assessed on roots collected from a 1-m section of a row. Each point represents the means of four replicates. Equations for logistic dose response curves are for 2005: $\mathrm{Y}=0.690+[1.26 / 1+(x / 27.0)]^{100}$, with $\mathrm{R}^{2}$ adj $=0.85, \mathrm{n}=8$; for 2006: $\mathrm{Y}=0.0876+[0.296 / 1+(x / 25.5)]^{7.70}$, with $\mathrm{R}^{2}$ adj $=0.77, \mathrm{n}=8$.

In 2006 , the model $\left(456 \mathrm{DD}_{7}{ }^{\circ} \mathrm{C}\right)$ predicted that $90 \%$ of the eggs were laid $\approx 18$ June 2006 , i.e., $2 \mathrm{~d}$ after the last cover was removed, at a time when plants were reaching

the critical developmental stage and when significant oviposition could occur. Root damage of uncovered plants was lower $(P<0.05)$ in 2006 ( 0.37 tunnel/root) than in 2005 (1.85 tunnel/root) (Fig. 3), probably reflecting both a low carrot weevil population and differences in climatic conditions as reported previously by Boivin (1999).

The effectiveness of the agrotextile floating rowcover in controlling carrot weevil damage depends on a combination of factors, including carrot weevil biology, crop growth, weather conditions, and time of rowcover removal. Based on these trials, covering carrots for $40 \mathrm{~d}$ with the floating rowcover after sowing reduced carrot weevil damage by $65 \%$ to $75 \%$. This reduction in damage would imply that under low and medium infestation levels of carrot weevils, no insecticide application is necessary. The protective effect of the floating rowcover may be beneficial to growers, particularly when accompanied by monitoring of carrot weevil activity to optimize the timing of floating rowcover removal.

\section{Literature Cited}

Benoit, F., N. Ceustermans, and A. Calus. 1983 The influence of the interaction between the degree of perforation of the plastics sheeting and the period of flat covering on the morphogenesis of early carrots. Plasticulture 58:11-17.

Benoit, F. and N. Ceustermans. 1990. Effect of the removal of the two direct cover sheetings on the development of carrots (Daucus carota L.). Acta Hort. 267:45-51.

Boivin, G. 1988. Effects of carrots development stages on feeding and oviposition of carrot weevil, Listronotus oregonensos (Le Conte) (Coleoptera: Curculionidae). Environ. Emtomol. 17:330-339.

Boivin, G. 1999. Integrated management for carrot weevil. Integrated Pest Manag. Rev. 4:21-37.

Costa, H.S., M.W. Johnson, and D.E. Ullman 1994. Row covers effect on sweet potato whitfly (Homoptera: Aleyrodidae) densities, incidence of silverleaf, and crop yield in zucchini. J. Econ. Entomol. 87:1616-1621.

Davies, J. and R. Collier. 2000. Strategies for controlling fly while minimizing pesticide inputs. Acta Hort. 533:575-582.

El-Zammar, S., Y. Abou-Jawdah, and H. Sobh. 2001. Management of virus diseases of squash in Lebanon. J. Plant Pathol. 83:2125.

Farias-Larios, J., M. Orozco-S, and J. Perez. 1999. Effect of plastic mulch, floating row cover and microtunnels on insect populations and yield of melon. Plasticulture 118:6-13.

Finch-Savage, W.E. 1986. The effects of fluid drilling and seed covering medium on early carrot production under polyethylene mulch. Ann. Appl. Biol. 108:431-439.

Finch-Savage, W.E., K. Phelps, J.R.A. Steckel, W.R. Whalley, and H.R. Rowse. 2001. Seed reserve-dependent growth responses to temperature and water potential in carrot (Daucus carota L.). J. Expt. Bot. 364:2187-2197.

Finch-Savage, W.E., J.R.A. Steckel, and K. Phelps. 1998. Germination and post-germination growth to carrot seedling emergence: Predictive threshold models and sources of variation between sowing occasions. New Phytol. 139:505-516.

Hartz, T.K. 1994. Minimizing environmental stress in field establishment of vegetable crops in the 
south-western United States. HortTechnology 4:29-34.

Jenni, S. 1989. Influence of a row cover and covering duration on growth and development of early mini carrot and crisphead lettuce in southern Quebec. McGill Univ., Sainte-Annede-Bellevue, Quebec. M.Sc. thesis.

Lamont, W.J. 1996. What are the components of a plasticulture vegetable system? HortTechnology 6:150-154.

Lamont, W.J. 2005. Plastics: Modifying the microclimate for the production of vegetable crops. HortTechnology 15:477-481.

Millar, K.V. and M.B. Isman. 1988. The effects of a spunbonded polyester row cover on cauliflower yields loss caused by insects. Can. Entomol. 120:45-47.
Orchard, T.J. 1977. Estimating the parameters of plant seedling emergence. Seed Sci. Technol. 5:61-69.

Orozco-S., M., O. Lopez-A, O. Perez-Z, and F. Delgadillo-S. 1994. Effect of transparent mulch, floating row covers and oil sprays on insect populations, virus diseases and yield of cantaloup. Biol. Agr. Hort. 10:229234.

Peacock, L. 1991. Effect on weed growth of shortterm cover over organically grown carrots. Biol Agr. Hort. 7:271-279.

Perring, T.M., R.N. Royalty, and C.A. Farrar. 1989. Floating row covers for the exclusion of virus vectors and the effect on disease incidence and yield of cantaloupe. J. Econ. Entomol. 82:1709-1715.
Rekika, D., K.A. Stewart, G. Boivin, and S. Jenni. 2008. Reduction of insect damage in radish with floating row covers. J. Veg. Sci. in press.

SAS Institute Inc. 1989. SAS user's guide, ver. 6.0. SAS Inst., Cary, NC.

Wells, O.S. and J.B. Loy. 1985. Intensive vegetable production with rowcovers. HortScience 20: 822-826.

Wells, O.S. and J.B. Loy. 1993. Row covers and high tunnels enhance crop production in northeastern United States. HortTechnology 3:92-95.

Zhao, D.X., G. Boivin, and R.K. Stewart. 1991. Simulation model for the population dynamics of the carrot weevil, Listronotus oregonensis (LeConte) (Coleoptera: Curculionidae). Can. Entomol. 123:63-76. 